\title{
Exhausted Yerba Mate Leaves (Ilex paraguariensis) as Biosorbent for the Removal of Metals from Aqueous Solutions
}

\author{
Guillermo J. Copello, ${ }^{a, b}$ Rodolfo E. Garibotti, ${ }^{a}$ Florencia Varela, ${ }^{a}$ \\ María V. Tuttolomondo and Luis E. Diaz, ${ }^{*, a, b}$ \\ ${ }^{a}$ Cátedra de Química Analítica Instrumental, Facultad de Farmacia y Bioquímica, Universidad de \\ Buenos Aires (UBA), Junín 956, C1113AAD Buenos Aires, Argentina \\ ${ }^{b}$ IQUIMEFA (UBA-CONICET), Junín 956,C1113AAD Buenos Aires, Argentina
}

\begin{abstract}
Erva mate é a bebida do tipo chá mais popular na América do Sul. Consequentemente, uma grande quatidade de resíduos da erva já usada é gerada, podendo ser usada na remoção de metais. Neste estudo, foi avaliada a capacidade das folhas de erva-mate esgotadas na remoção de metais. A maior adsorção foi observada em pHs abaixo de 5. A capacidade de adsorção das folhas de erva-mate foi de $12,28,11,77$ e $8,80 \mathrm{mg} \mathrm{g}^{-1}$ para $\mathrm{Pb}(\mathrm{II}), \mathrm{Cr}(\mathrm{III})$ e $\mathrm{Cr}(\mathrm{VI})$, respectivamente.
\end{abstract}

Yerba mate is the most popular tea-like beverage of South America. Consequently, there is a huge generation of residues of exhausted yerba mate and these may be used for removal of metals. The capability of exhausted yerba mate leaves in the removal of metals was evaluated in this study. The greatest adsorption was found to be at pHs below 5 and the adsorption capacity was 12.28 , 11.77 and $8.80 \mathrm{mg} \mathrm{g}^{-1}$ for $\mathrm{Pb}(\mathrm{II}), \mathrm{Cr}(\mathrm{III})$ and $\mathrm{Cr}(\mathrm{VI})$, respectively.

Keywords: yerba mate, lead, chromium, metal removal, biosorbent

\section{Introduction}

Although water pollution includes a wide spectrum of sources, at present the main concern is focused on the presence of organic and inorganic chemical products. ${ }^{1}$ Among the last pollutants, metals are a serious environmental and sanitary problem. Metal ions appear in natural waters and industrial effluents mainly due to anthropogenic activities, such as metal plating, mining and tanning. ${ }^{2}$

During the last decades, it has been used technologies applying low cost sorbents for water remediation as an alternative to expensive methods such as membrane filtration, ion exchange or activated carbon adsorption. ${ }^{3}$ A sorbent can be considered as "low cost" if it requires little or none processing, or if it is a by-product or waste material that could be obtained in abundance. ${ }^{4}$ Among low cost sorbents, biosorbents are those obtained from a biological source. Biosorbents may be made from agricultural wastes, such as grainless stalk of corn, sugar beet pulp, different kinds of tea, exhausted ground coffee

\footnotetext{
*e-mail: ldiaz@ffyb.uba.ar
}

waste or from other sources, such as microbial biomass, algal biomass, vermicompost, peat moss, chitin and chitosan. ${ }^{5-12}$ Complete reviews on the use of low-cost adsorbents for the removal of metals has been presented by Bailey et al. ${ }^{4}$ and Sud et al. ${ }^{13}$

The consumption of yerba mate infusion is the most popular tea-like beverage of South America. ${ }^{14}$ Only in Argentina 280,000 tons of yerba mate are cultivated per year. Yerba mate (Ilex paraguariensis) dry leaves (about $50 \mathrm{~g}$ ) are packed into a gourd (mate) and hot water is poured over them; then the infusion is sipped with a straw. ${ }^{15}$ This process is repeated several times. After the consumption the leaves are discarded as useless waste.

The aim of this study is to evaluate the capability of yerba mate leaves, which had been used for the infusion consumption, in the removal of metals from an aqueous solution. $\mathrm{Pb}$ (II), $\mathrm{Cr}$ (III) and $\mathrm{Cr}(\mathrm{VI})$ were chosen as model metals. Conditions of batch adsorption such as adsorption times, pHs and adsorption capacity were studied. Langmuir, Freundlich and Dubinin-Radushkevich isotherm models were analyzed together with the evaluation of adsorption energy and Gibbs free energy $\left(\Delta G^{0}\right)$. 


\section{Experimental}

\section{Materials}

Yerba mate leaves (Ilex paraguariensis) were used from commercially available herbal products. Chromium chloride was acquired from Riedel-de Haën (Seelze, Germany). Lead chloride was purchased from Merck (Darmstadt, Germany). Potassium dichromate was acquired from Anedra (Bs. As., Argentina). Nitric Acid (70\% v/v) was purchased from J. T. Baker (Phillipsburg, NJ, USA). Water was filtered and deionized with a Milli-Q, Millipore system (Milford, MA, USA). All other reagents were of analytical grade.

\section{Yerba mate leaves conditioning}

Yerba mate leaves were assayed with two conditioning methods, and named accordingly: (i) Non-Exhausted leaves: Yerba mate leaves $(50 \mathrm{~g})$ directly from the commercial package were boiled in $1 \mathrm{~L}$ of ultrapure water for $10 \mathrm{~min}$, filtered and then dried at $37{ }^{\circ} \mathrm{C}$; (ii) Exhausted leaves: Yerba mate leaves ( $50 \mathrm{~g}$ per gourd) used for consumption as an infusion, sipped with a straw several times by pouring $25 \mathrm{~mL}$ of hot water at $70^{\circ} \mathrm{C}$ into the gourd. This procedure was repeated until the leaves had been in contact with $1 \mathrm{~L}$ of hot water (40 cycles). Then, the exhausted leaves were dried at $37^{\circ} \mathrm{C}$.

\section{Adsorption experiments}

Adsorption experiments were carried out by a batch method at room temperature $\left(25^{\circ} \mathrm{C}\right)$. Dried non-exhausted and exhausted leaves $(0.25 \mathrm{~g})$ were added to different aqueous solutions (50 mL), each containing $\mathrm{Pb}(\mathrm{II}), \mathrm{Cr}$ (III) or $\mathrm{Cr}(\mathrm{VI})$ ranging from 0.5 to $100 \mathrm{mg} \mathrm{L}^{-1}$. The effect of
pH on metal adsorption, adsorption times and adsorption isotherms were determined by monitoring metal decay in the solution supernatant. For the analysis of the adsorption isotherms, in order to evaluate the mass of metal adsorbed in the sorbent, microwave digestion (MLS 1200 Mega, Milestone, Bergamo, Italy) of the leaves was carried out in a $\mathrm{HNO}_{3}: \mathrm{H}_{2} \mathrm{O}_{2}$ mixture $(9: 1 \mathrm{v} / \mathrm{v})$ prior to electrothermal atomic absorption spectrometry (ETAAS) determination.

Under the experimental conditions, a $\mathrm{pH}$ range from 2 to 8 and $72 \mathrm{~h}$ of incubation, it was verified that no chemical precipitation occurred. After each experiment, solutions were ultracentrifuged and analyzed for the concentration of metals. For all tests, blank experiments were performed using solutions without metal spiking or without the addition of yerba mate leaves. All experiments and measurements were conducted in duplicate under identical conditions.

\section{Atomic absorption spectrometry}

Metal determinations were made with a Buck Scientific VGP 210 atomic absorption spectrometer (E. Norwalk, CT, USA) by the electrothermal atomization method using pyrolytic graphite tubes. Nickel nitrate $0.1 \% \mathrm{~m} / \mathrm{v}$ was used as matrix modifier for lead determination. Each sample was injected in triplicate.

\section{Results and Discussion}

\section{Effect of $p H$ on adsorption behavior}

The influence of aqueous solution $\mathrm{pH}$ on yerba mate metal adsorption was investigated in the $\mathrm{pH}$ range 2-8 (Table 1). Higher $\mathrm{pHs}$ than 7 were not evaluated for $\mathrm{Pb}$ (II) and $\mathrm{Cr}(\mathrm{III})$ because $\mathrm{Pb}(\mathrm{OH})_{2}$ and $\mathrm{Cr}(\mathrm{OH})_{3}$ precipitates above $\mathrm{pH} 8 .{ }^{16}$ The adsorption of exhausted and nonexhausted yerba mate leaves is compared in Table 1.

Table 1. Effect of $\mathrm{pH}$ on the adsorption of $15 \mathrm{mg} \mathrm{L}^{-1} \mathrm{~Pb}(\mathrm{II}), \mathrm{Cr}(\mathrm{III})$ and $\mathrm{Cr}(\mathrm{VI})$ on exhausted and non-exhausted yerba mate leaves

\begin{tabular}{lcccccc}
\hline & \multicolumn{5}{c}{ Adsorption (\%) } \\
\cline { 2 - 7 } & \multicolumn{2}{c}{$\mathrm{Pb}(\mathrm{II})$} & \multicolumn{2}{c}{$\mathrm{Cr}(\mathrm{III})$} & \multicolumn{2}{c}{$\mathrm{Cr}(\mathrm{VI})$} \\
\cline { 2 - 7 } & Non-Exhausted & Exhausted & Non-Exhausted & Exhausted & Non-Exhausted & Exhausted \\
\hline pH 2 & $75.7 \pm 0.3$ & $76.4 \pm 0.4$ & $13.0 \pm 0.6$ & $20.9 \pm 0.9$ & $35.2 \pm 0.8$ & $40.9 \pm 2.5$ \\
pH 3 & $76.2 \pm 0.8$ & $74.4 \pm 2.6$ & $43.2 \pm 0.5$ & $40.9 \pm 0.7$ & $29.9 \pm 0.4$ & $29.2 \pm 1.2$ \\
pH 4 & $70.7 \pm 1.9$ & $75.0 \pm 4.6$ & $32.8 \pm 1.3$ & $39.4 \pm 1.4$ & $24.2 \pm 0.6$ & $33.3 \pm 0.2$ \\
pH 5 & $74.3 \pm 4.0$ & $73.1 \pm 6.6$ & $12.2 \pm 1.4$ & $16.9 \pm 0.5$ & $27.7 \pm 0.2$ & $30.3 \pm 1.1$ \\
pH 6 & $39.2 \pm 2.6$ & $48.3 \pm 8.7$ & $32.4 \pm 1.6$ & $22.7 \pm 2.3$ & $21.9 \pm 0.6$ & $29.8 \pm 2.1$ \\
pH 7 & $1.1 \pm 0.9$ & $3.9 \pm 1.6$ & $6.2 \pm 2.0$ & $13.3 \pm 1.5$ & $5.7 \pm 0.8$ & $2.8 \pm 2.6$ \\
pH 8 & N.T. & N.T. & N.T. & N.T. & $18.3 \pm 1.1$ & $9.7 \pm 1.5$ \\
\hline
\end{tabular}

N.T.: Not Tested. 
Metal adsorption on yerba mate was greater at lower pHs. Meanwhile $\mathrm{Pb}$ (II) adsorption shows an increase at $\mathrm{pH}<5, \mathrm{Cr}(\mathrm{III})$ adsorption showed to be higher from $\mathrm{pH} 3$ to 4 . $\mathrm{Cr}(\mathrm{VI})$ adsorption was low at high $\mathrm{pHs}$ and only slightly higher at $\mathrm{pH} 2$. Recent studies proposed that the true mechanism of $\mathrm{Cr}(\mathrm{VI})$ biosorption is an adsorptioncoupled reduction process. ${ }^{5,17,18} \mathrm{Cr}(\mathrm{VI})$ would be reduced to $\mathrm{Cr}(\mathrm{III})$ in acidic conditions by organic compounds from the biosorbent. The latter chromium specie would be the one that is truly adsorbed. In most biosorption cases, although decreasing $\mathrm{pH}$ media promotes $\mathrm{Cr}(\mathrm{VI})$ reduction, it also decreases $\mathrm{Cr}(\mathrm{III})$ adsorption by electrostatic repulsion of the cation and protonated groups in the biosorbent. This is not the case of yerba mate leaves where major $\mathrm{Cr}(\mathrm{III})$ adsorption is observed at acidic media, which makes the $\mathrm{Cr}(\mathrm{VI})$ adsorption-coupled reduction process possible.

Exhausted leaves adsorption was equal or slightly higher compared to non-exhausted leaves at all $\mathrm{pHs}$ and for all metals. The temperature of the water used for making the infusion was lower $\left(70^{\circ} \mathrm{C}\right)$ than water boiling temperature, which was used for conditioning non-exhausted leaves. Thus, the latter were subjected to a more aggressive conditioning which could lead to a higher solubilization of adsorbent components of the yerba mate. Being exhausted leaves the waste of yerba mate consumption, all further experiments were conducted using exhausted leaves and media were adjusted to the optimum adsorption $\mathrm{pH}$ of each metal.

Polyphenol compounds, like tannins, are described in literature as responsible for herbal leaves metal quelating activity due to its $o$-dihydroxyphenyl groups. ${ }^{19-21}$ Most of these compounds have acid groups in its structure and are extracted in aqueous media at high $\mathrm{pHs} .{ }^{22}$ At low $\mathrm{pHs}$ metal quelating compounds remain insoluble in yerba mate leaves causing greater metal adsorption by the biosorbent than at higher $\mathrm{pHs}$. In order to evaluate if yerba mate metal quelating compounds were being eluted from the leaves at high $\mathrm{pHs}$, different sets of exhausted leaves were subjected to up to four incubation cycles (at $\mathrm{pH} 7$ for $24 \mathrm{~h}$ at room temperature). Then, they were incubated in a $15 \mathrm{mg} \mathrm{L}^{-1} \mathrm{~Pb}$ (II) solution at $\mathrm{pH} 4$ for $24 \mathrm{~h}$ at room temperature. In comparison with the adsorption percentage of leaves that were not incubated at $\mathrm{pH} 7$ (100 \pm 0.8 ), a decay could be seen in $\mathrm{Pb}$ (II) adsorption with the increase of the number of $\mathrm{pH} 7$ incubation cycles that the exhausted leaves were exposed. For the first, second, third and fourth cycles the adsorption percentages were 96.3 $\pm 0.5,87.4 \pm 0.7,84 \pm 3$, and $77.5 \pm 0.9$, respectively. This confirms the elution from the yerba mate leaves of the metal quelating compounds at $\mathrm{pH} 7$.

The interaction of metals with polyphenols generate insoluble complexes, either by formation of an uncharged
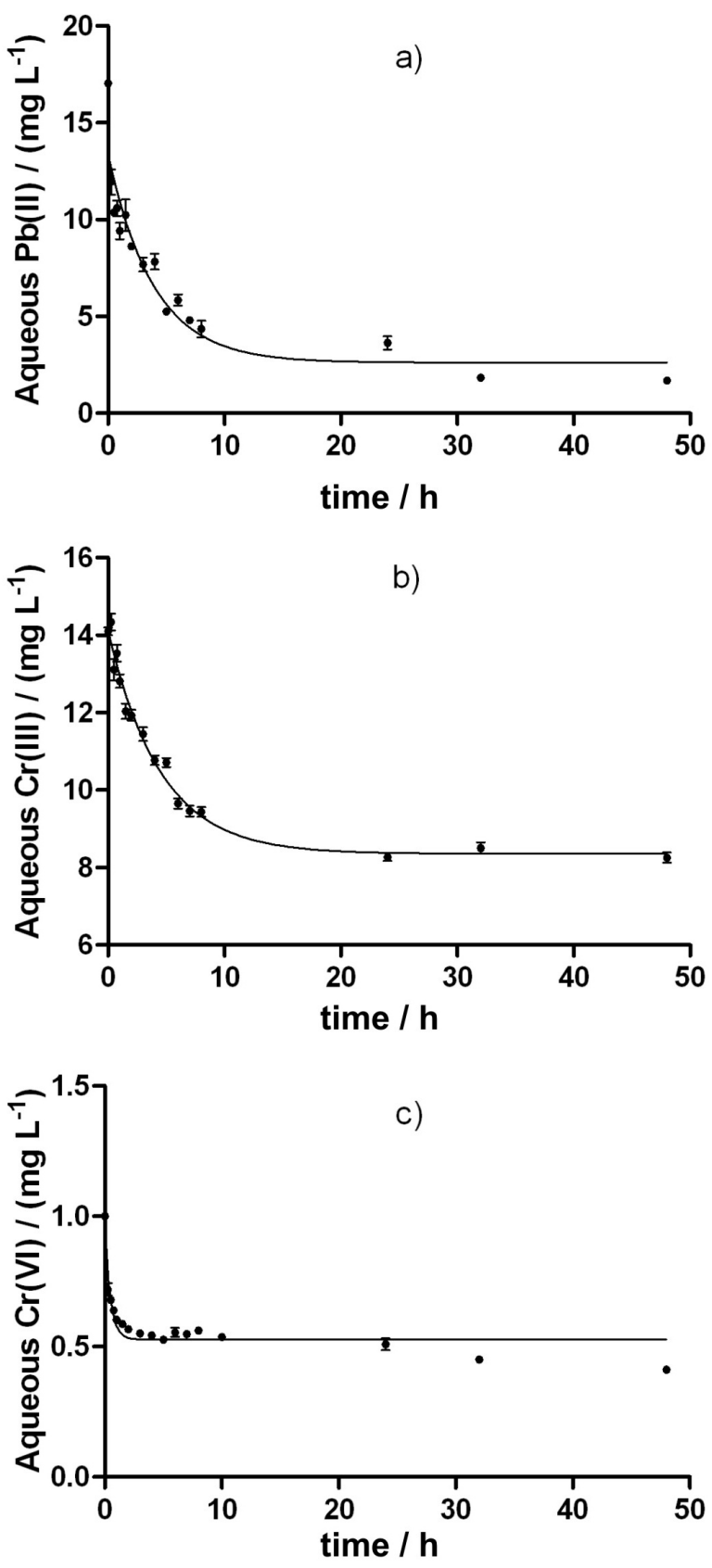

Figure 1. Aqueous metal concentration over time for initial concentrations of $17 \mathrm{mg} \mathrm{L}^{-1} \mathrm{~Pb}$ (II) at $\mathrm{pH} 3$ (a), $14 \mathrm{mg} \mathrm{L}^{-1} \mathrm{Cr}$ (III) at pH 3 (b) and $1.0 \mathrm{mg} \mathrm{L}^{-1}$ $\mathrm{Cr}(\mathrm{VI})$ at $\mathrm{pH} 2$ (c) exposed exhausted leaves.

metal complex, reduction of the polarity of the tannin molecule, or formation of high molecular weight complexes. ${ }^{23}$ By maintaining experimental conditions at a $\mathrm{pH}$ below 7 the interaction of metals with polyphenols occurs inside the leaves and facilitates the removal of the adsorbed metals.

\section{Adsorption times}

Adsorption kinetic experimental results are shown in Figure 1. These plots show aqueous ion concentration over 
time. In order to analyze the ions uptake rates a simple kinetic analysis using the pseudo-first-order equation was tested: ${ }^{24}$

$C_{t}=C_{e q}+C_{x} e^{-k \cdot t}$

where $C_{t}$ and $C_{e q}$ are aqueous metal concentration at time $t$ and at equilibrium respectively $\left(\mathrm{mg} \mathrm{L}^{-1}\right), C_{x}$ is the difference between metal initial concentration $\left(C_{0}\right)$ and $C_{e q}$ $\left(\mathrm{mg} \mathrm{L}^{-1}\right)$. The modeled kinetic parameters are summarized in Table 2. For $\mathrm{Pb}$ (II) and $\mathrm{Cr}$ (III) the aqueous concentration of equilibrium was reached within $16 \mathrm{~h}$ incubation. A higher uptake rate was observed for $\mathrm{Cr}(\mathrm{VI})$. It could be expected that at low $\mathrm{pH}$, protonable compounds in yerba mate leaves would rather attract an anionic ion, like chromate species, than cations, such as $\mathrm{Pb}$ (II) and $\mathrm{Cr}$ (III), which would suffer electrostatic repulsion before interacting with the adsorption sites. All further experiments were carried with a minimum of $16 \mathrm{~h}$ incubation in order to assure that all metal had achieved equilibrium.

\section{Adsorption isotherms}

Langmuir and Freundlich isotherms were modeled in order to evaluate its application in the sorption process characterization. Langmuir and Freundlich adsorption isotherms can be expressed using equations (2) and (3) respectively as follows: ${ }^{25}$

$q_{e q}=\frac{q_{m} K_{a} C_{e q}}{1+K_{a} C_{e q}}$

$q_{e q}=k C_{e q}^{n}$

where $q_{e q}$ is the amount of adsorbed metal per unit mass of sorbent at equilibrium ( $\left.\mathrm{mg} \mathrm{g}^{-1}\right), K_{a}$ is the adsorption equilibrium constant $\left(\mathrm{L} \mathrm{mg}^{-1}\right), q_{m}$ is the maximum adsorption capacity $\left(\mathrm{mg} \mathrm{g}^{-1}\right)$, and $k$ and $n$ are arbitrary parameters, the dimensions of $k$ depend on the value of $n \cdot{ }^{25}$ The adsorption isotherms are shown in Figure 2, where Langmuir and Freundlich plots are also represented. Parameters obtained for the nonlinear regression of Langmuir and Freundlich models are summarized in Table 3 . The values of $q_{m}$ were found to be similar to other polyphenol containing biosorbents reported in literature. , $^{4,17}$
The $q_{m}$ for $\mathrm{Cr}(\mathrm{VI})$ showed to be slightly lower than for $\mathrm{Pb}(\mathrm{II})$ and $\mathrm{Cr}$ (III). Considering that $\mathrm{Cr}(\mathrm{VI})$ interact with the yerba mate leaves by an adsorption-coupled reduction mechanism it could be expected that $\mathrm{Cr}(\mathrm{VI})$ reduction occurs by oxidation of polyphenols. This would
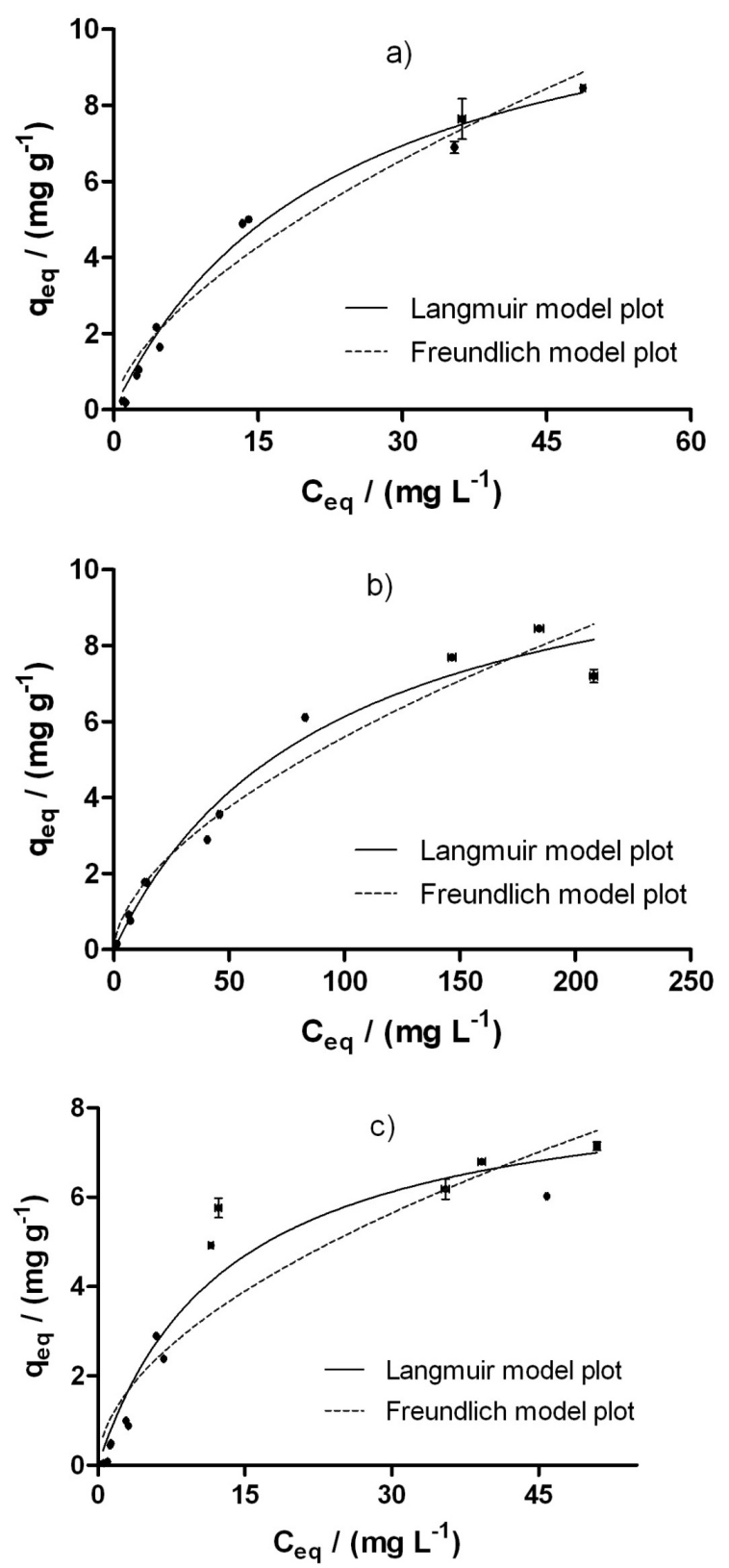

Figure 2. Adsorption isotherms for $\mathrm{Pb}$ (II) at $\mathrm{pH} 3$ (a), $\mathrm{Cr}(\mathrm{III}) \mathrm{pH} 3$ (b) and $\mathrm{Cr}(\mathrm{VI})$ at pH 2 (c). Langmuir and Freundlich plots are represented.

Table 2. Kinetic parameters for $\mathrm{Pb}(\mathrm{II}), \mathrm{Cr}(\mathrm{III})$ and $\mathrm{Cr}(\mathrm{VI})$ adsorption on exhausted yerba mate leaves

\begin{tabular}{lcccc}
\hline Metal & $C_{x}\left(\mathrm{mg} \mathrm{L}^{-1}\right)$ & $k\left(\mathrm{~h}^{-1}\right)$ & $C_{e q}\left(\mathrm{mg} \mathrm{L}^{-1}\right)$ & $\mathrm{R}^{2}$ \\
\hline $\mathrm{Pb}(\mathrm{II})$ & $10.76 \pm 0.48$ & $0.25 \pm 0.03$ & $2.62 \pm 0.36$ & 0.854 \\
$\mathrm{Cr}(\mathrm{III})$ & $5.78 \pm 0.15$ & $0.22 \pm 0.01$ & $8.35 \pm 0.11$ & 0.947 \\
$\mathrm{Cr}(\mathrm{VI})$ & $0.44 \pm 0.02$ & $2.14 \pm 0.20$ & $0.527 \pm 0.006$ & 0.849 \\
\hline
\end{tabular}


Table 3. Adsorption parameters for $\mathrm{Pb}(\mathrm{II}), \mathrm{Cr}(\mathrm{III})$ and $\mathrm{Cr}(\mathrm{VI})$ adsorptions on exhausted yerba mate leaves

\begin{tabular}{|c|c|c|c|c|c|c|}
\hline & \multicolumn{3}{|c|}{ Langmuir } & \multicolumn{3}{|c|}{ Freundlich } \\
\hline & $q_{m}\left(\mathrm{mg} \mathrm{g}^{-1}\right)$ & $K_{a}\left(\mathrm{~L} \mathrm{mg}^{-1}\right)$ & $\mathrm{R}^{2}$ & $k$ & $n$ & $\mathrm{R}^{2}$ \\
\hline $\mathrm{Pb}(\mathrm{II})$ & $12.28 \pm 0.62$ & $0.043 \pm 0.005$ & 0.982 & $0.802 \pm 0.095$ & $0.618 \pm 0.034$ & 0.959 \\
\hline $\mathrm{Cr}(\mathrm{III})$ & $11.77 \pm 0.59$ & $0.011 \pm 0.001$ & 0.979 & $0.389 \pm 0.057$ & $0.579 \pm 0.029$ & 0.964 \\
\hline $\mathrm{Cr}(\mathrm{VI})$ & $8.80 \pm 0.45$ & $0.076 \pm 0.011$ & 0.947 & $0.916 \pm 0.135$ & $0.535 \pm 0.042$ & 0.889 \\
\hline
\end{tabular}

lead to a decrease in the number of adsorption sites and, therefore, a lower adsorption capacity. The exhausted yerba mate leaves showed to have a better adjustment for the Langmuir model than for the Freundlich one. Langmuir model presents good experimental agreement for systems with homogeneous monolayer adsorption for a single specie of the metal from the liquid to the solid phase. ${ }^{7}$ The equilibrium data was also consistent with the Freundlich model which presents a better adjustment to materials with heterogeneous adsorption sites. This is probably due to a wide variety of polyphenols acting as quelating agents in yerba mate leaves.

The favorability of adsorption within the range of metal concentrations assayed was confirmed by the separation factor $\left(R_{L}\right)$, which indicates the shape of the isotherm and the favorability of the adsorption process. The adsorption is unfavorable when $R_{L}>1$, linear when $R_{L}=1$, favorable when $0<R_{L}<1$, and irreversible when $R_{L}=0$. The values of $R_{L}$ for each initial metal concentration were calculated using equation (4):26

$R_{L}=1 /\left(1+K_{a} C_{0}\right)$

For $\mathrm{Pb}(\mathrm{II}) R_{L}$ values from 0.958 to 0.187 were obtained in the concentration range from 1 to $100 \mathrm{mg} \mathrm{L}^{-1}$. For $\mathrm{Cr}$ (III) and $\mathrm{Cr}$ (VI) $R_{L}$ values from 0.995 to 0.479 and 0.963 to 0.116 were obtained, respectively, in the concentration range from 0.5 to $100 \mathrm{mg} \mathrm{L}^{-1}$. From these results it can be concluded that the adsorption was favorable within the whole range of metal concentrations used in this study.

\section{Evaluation of adsorption energy and Gibbs free energy}

The equilibrium data shown as points in Figure 2 have been analyzed by Dubinin-Radushkevich (D-R) equation (5). For liquid-solid phase adsorption the amount adsorbed corresponding to any adsorbate concentration is assumed to be a Gaussian function of the Polanyi potential, $\varepsilon: 27,28$

$q_{e q}=q_{D R} e^{-K_{D R} \varepsilon^{2}}$

with

$\varepsilon=R T \ln \left(1+1 / C_{e q}\right)$

where $q_{D R}$ is the maximum adsorption capacity $\left(\mathrm{mg} \mathrm{g}^{-1}\right), K_{D R}$ is a constant related to sorption energy $\left(\mathrm{mol}^{2} \mathrm{~kJ}^{-2}\right), R$ the gas constant $\left(\mathrm{kJ} \mathrm{mol}^{-1} \mathrm{~K}^{-1}\right)$, and $T$ the absolute temperature $(\mathrm{K})$.

If the adsorbent surface is heterogeneous and homogeneous subregions are considered, an average free energy value could be calculated using equation (7): ${ }^{29}$

$E_{D R}=\left(2 K_{D R}\right)^{-1 / 2}$

where $E_{D R}$ is the mean free energy of adsorption $\left(\mathrm{kJ} \mathrm{mol}^{-1}\right)$, this magnitude is useful for estimating the type of adsorption reaction, being the range of 8 to $16 \mathrm{~kJ} \mathrm{~mol}^{-1}$ related to ion exchange reactions. ${ }^{26}$

The Gibbs free energy $\left(\Delta G^{0}\right)$ of the process is related to the adsorption equilibrium constant $\left(K_{a}\right)$ by the following equation (8): ${ }^{30}$

$\Delta G^{0}=-R T \ln K_{a}$

Table 4 summarizes the D-R parameters together with $E_{D R}$ and $\Delta G^{0}$ values. The adsorption of the three ions tested showed good agreement to D-R isotherm model. The mean free energy of adsorption calculated for the interaction of

Table 4. D-R parameters, $E_{D R}$ and $\Delta G^{0}$ for $\mathrm{Pb}(\mathrm{II}), \mathrm{Cr}(\mathrm{III})$ and $\mathrm{Cr}(\mathrm{VI})$

\begin{tabular}{lccccc}
\hline & \multicolumn{5}{c}{$\mathrm{D}-\mathrm{R}$} \\
\cline { 2 - 6 } & $q_{D R}\left(\mathrm{mg} \mathrm{g}^{-1}\right)$ & $K_{D R}\left(\mathrm{~mol}^{2} \mathrm{~kJ}^{-2}\right)$ & $\mathrm{R}^{2}$ & $E_{D R}\left(\mathrm{~kJ} \mathrm{~mol}^{-1}\right)$ & $\Delta G^{0}\left(\mathrm{~kJ} \mathrm{~mol}^{-1}\right)$ \\
\hline $\mathrm{Pb}(\mathrm{II})$ & $133.5 \pm 20.4$ & $0.0045 \pm 0.0002$ & 0.967 & $10.54 \pm 0.26$ & $-22.56 \pm 0.05$ \\
$\mathrm{Cr}(\mathrm{III})$ & $70.7 \pm 8.2$ & $0.0048 \pm 0.0002$ & 0.971 & $10.19 \pm 0.24$ & $-15.71 \pm 0.05$ \\
$\mathrm{Cr}(\mathrm{VI})$ & $74.2 \pm 14.5$ & $0.0038 \pm 0.0003$ & 0.905 & $11.41 \pm 0.43$ & $-20.53 \pm 0.06$ \\
\hline
\end{tabular}


$\mathrm{Pb}(\mathrm{II}), \mathrm{Cr}(\mathrm{III})$ was the typical of an ion exchange reaction, as would be expected from the presence of $o$-dihydroxyphenyl metal chelating groups in polyphenolic structures. ${ }^{23}$ In the case of $\mathrm{Cr}(\mathrm{VI})$ considering the adsorption-coupled reduction, the mean free energy of adsorption value also accounts for an ion exchange reaction. This probably means that the overall adsorption process is leaded by the $\mathrm{Cr}(\mathrm{III})$ adsorption after the reduction. The negative values obtained for the standard free energy for all three ions tested shows the spontaneity of the process at these conditions.

\section{Conclusions}

Yerba mate exhausted leaves demonstrated to effectively adsorb $\mathrm{Pb}(\mathrm{II}), \mathrm{Cr}(\mathrm{III})$, and $\mathrm{Cr}(\mathrm{VI})$ from aqueous solution. The $\mathrm{pH}$ of the medium was found to be involved in polyphenols extraction from the leaves, thus affecting their metal quelating activity. Metal adsorption followed an ion exchange spontaneous reaction as the main mechanism. The metal adsorption capacity of exhausted yerba mate leaves demonstrated to be similar to other polyphenol containing materials.

This study suggests the applicability of this costeffective biosorbent in the removal of toxic metal ions. In Argentina the preparation of this infusion is so widely spread, at homes as well as at working and educational places, that the INDEC (National Institute for Statistics and Census) has included it in the Basic Shopping Basket. Its monthly consumption per family is estimated around $600 \mathrm{~g}$. The fact that large quantities of yerba mate are consumed and discarded every day in South America makes this biosorbent extremely inexpensive and highly available encouraging an evaluation at a scale up procedure.

\section{Acknowledgments}

G. J. C. is grateful for their postdoctoral fellowship granted by CONICET. This work was supported with grants from Universidad de Buenos Aires (UBACYT B049). The authors would like to thank Professor M. L. Gonzalez for language corrections.

\section{References}

1. Manahan, S. E.; Introducción a la Quimica Ambiental, Reverté: Barcelona, España, 2007.

2. Berman, E.; Toxic Metals and their Analysis, Heyden \& Sons: London, 1980.

3. Gadd, G. M.; J. Chem. Tech. Biotechnol. 2009, 84, 13.

4. Bailey, S.; Olin, T.; Bricka, R.; Adrian, D.; Water Res. 1999, 33, 2469.
5. Bellú, S.; García, S.; González, J. C.; Atria, A. M.; Sala, L. F.; Signorella, S.; Sep. Sci. Technol. 2008, 43, 3200.

6. Minamisawa, M.; Minamisawa, H.; Yoshida, S.; Takai, N.; J. Agric. Food Chem. 2004, 52, 5606.

7. Ho, Y.; McKay, G.; Water Res. 2000, 34, 735.

8. Reddad, Z.; Gerente, C.; Andres, Y.; Le Cloirec, P.; Environ. Sci. Technol. 2002, 36, 2067.

9. Pereira, M. G.; Arruda, M. A. Z.; J. Braz. Chem. Soc. 2003, 14, 39.

10. Duarte, M. M. M. B.; da Silva, J. E.; Passavante, J. Z. D. O.; Pimentel, M. F.; de Barros Neto, B.; da Silva, V. L.; J. Braz. Chem. Soc. 2001, 12, 449.

11. Leusch, A.; Holan, Z. R.; Volesky, B.; J. Chem. Tech. Biotechnol. 1995, 62, 279.

12. Longhinotti, E.; Pozza, F.; Furlan, L.; de M. Sanchez, M. D. N.; Klug, M.; Laranjeira, M. C.; Fávere, V. T.; J. Braz. Chem. Soc. 1998, 9, 435.

13. Sud, D.; Mahajan, G.; Kaur, M. P.; Bioresource Technol. 2008, 99, 6017.

14. Filip, R.; Lopez, P.; Giberti, G.; Coussio, J.; Ferraro, G.; Fitoterapia 2001, 72, 774.

15. Heck, C. I.; de Mejia, E. G.; J. Food Sci. 2007, 72, 138.

16. Burriel Martí, F.; Lucena, F.; Arribas, S.; Hernández, J.; Química Analítica Cualitativa, Paraninfo: Madrid, 1989.

17. Elangovan, R.; Philip, L.; Chandraraj, K.; J. Hazard. Mater. 2008, 152, 100.

18. Park, D.; Lim, S.; Yun, Y.; Park, J. M.; Bioresource Technol. 2008, 99, 8810.

19. Beltran Heredia, J.; Sanchez Martin, J.; J. Hazard. Mater. 2009, 165, 1215.

20. Yurtsever, M.; Sengil, I. A.; J. Hazard. Mater. 2009, 163, 58.

21. Lavid, N.; Schwartz, A.; Yarden, O.; Tel-Or, E.; Planta 2001, 212, 323 .

22. Campo Dall'Orto, V.; Vago, J.; Carballo, R.; Rezzano, I.; Anal. Lett. 2005, 38, 19 .

23. McDonald, M.; Mila, I.; Scalbert, A.; J. Agric. Food Chem. 1996, 44, 599.

24. Copello, G. J.; Varela, F.; Vivot, R. M.; Diaz, L. E.; Bioresour. Technol. 2008, 99, 6538.

25. Suen, S.; J. Chem. Tech. Biotechnol. 1996, 65, 249.

26. Debnath, S.; Ghosh, U.; J. Chem. Thermodyn. 2008, 40, 67.

27. Barton, S.; J. Colloid Interface Sci. 1993, 158, 64.

28. El-Kamash, A.; Zaki, A.; El Geleel, M.; J. Hazard. Mater. 2005, 127,211

29. Hsieh, C.; Teng, H.; J. Chem. Tech. Biotechnol. 2000, 75, 1066. 30. da Fonseca, M. G.; de Oliveira, M. M.; Arakaki, L. N.; Espinola, J. G.; Airoldi, C.; J. Colloid Interface Sci. 2005, 285, 50.

Submitted: July 30, 2010

Published online: January 18, 2011 